\title{
Managing Differences and Building Trust: Challenges to U.S. - China Relations
}

\author{
Nur Rachmat Yuliantoro \\ Jurusan Ilmu Hubungan Internasional, Fakultas Ilmu Sosial dan Ilmu Politik, \\ Universitas Gadjah Mada
}

\begin{abstract}
The relations between two great nations, the United States and China, have attracted the attention of many. Different in several aspects, both countries face a number of challenges and problems in their relationship, ranging from misperception, mutual distrust, and the potential for conflict in the South China Sea as well as East China Sea. The leaders of both countries have difficult task to drive the bilateral relations positively for mutual benefit. This article demonstrates that while to some extent their differences are difficult to settle, they need to be put aside to build mutual trust as a basic ground for cooperation. Unfortunately, it seems that their relations in the future has still characterized, among others, by the absence of the will to understand each other.
\end{abstract}

Keywords: The United States, China, bilateral relations

\begin{abstract}
Abstrak
Hubungan antara dua negara adidaya, Amerika Serikat dan Cina, telah menyita perhatian banyak kalangan. Berbeda dalam beberapa aspek, kedua negara menghadapi beberapa tantangan dan persoalan dalam hubungan mereka, mulai dari persepsi yang keliru, saling tidak percaya, hingga potensi konflik di Laut Cina Selatan dan Laut Cina Timur. Para pemimpin kedua negara memikul tugas yang tidak ringan untuk mengarahkan hubungan bilateral secara positif demi kepentingan bersama. Artikel ini ingin menunjukkan bahwa sekalipun dalam tingkat tertentu, perbedaan antara keduanya sulit untuk dipertemukan, tetapi perbedaan-perbedaan itu harus dikesampingkan untuk membangun rasa saling percaya sebagai dasar kerjasama. Sayangnya, tampak bahwa hubungan kedua negara di masa depan masih belum bisa lepas sepenuhnya dari tiadanya kehendak untuk saling memahami.
\end{abstract}

Kata kunci: Amerika Serikat, Cina, hubungan bilateral 
"The U.S. and China face many common challenges in a period of rapid globalizationand growing strategic interdependence.

Successful cooperation ... could serve to reduce lingering suspicions of each other'sstrategic intentions and pave the way for

the development of 'normal' relations between the two countries."

(Garrett, 2006: 390)

"China-U.S relationship is neither to be too good nor to betoo bad (hao bu dao na li qu, ye huai bu dao na li $q u) . "$

(Deng Xiaoping, as quoted in Zhang \& Zheng, 2012: 624)

In my research project on the 2012 U.S. presidential election, I wrote that the election result would have soon been followed by some challenges faced by this superpower country in its international relations (Yuliantoro, 2012). One of the most important challenges would come from the Asia Pacific region. Based on President Barack Obama's statement before 2011, followed by an article in Foreign Policy written by Secretary of State Hillary Clinton (2011), Asia Pacific now occupies a key position in American foreign policy priorities. It is widely known that the economy of many countries in Asia Pacific continues to grow rapidly, in which emerging states like China and India continue to establish themselves as strong military forces and regional powers.

The United States is now "pivoting to Asia" as it increasingly affirms its foothold in Asia Pacific. Broadly speaking, the U.S.

${ }^{1}$ See, for example, Jones, H. (2010) Chin America: The Uneasy Partnership that Will Change the World. New York: McGraw Hill; Sujian Guo \& Baogang Guo (2010) 30 Years of China-U.S. Relations: Analytical Approaches and Contemporary Issues. Lanham: Lexington Books; Yufan Hao (2010) Sino-American Relations: challenges ahead. Surrey: Ashgate; Grafstein, R.\& Wen Fan eds. involvement in the region is expected to be more massive as it is to secure American longterm interests while responding to the rise of China and uncertainty about the continuing U.S. presence in the region. Within this context, senior adviser at the Center for a New American Security, Patrick Cronin (2012), argues that "Obama's rebalancing of priorities toward Asia is designed to reassure allies and new partners, without overly provoking a China vital to the global economy." The U.S. understands that China is a very important factor to be considered in strengthening America's influence in the region. Obama and Xi Jinping, who assumes the head of Chinese fifth generation leadership, must be mutually convinced that the combined economic strength of both countries are far more important to the prosperity of the world rather than the (pursuit of) hegemonic power. The United States and China that could be 'friends' will be key to the success of American strategy in facing various challenges in Asia Pacific.

It is also interesting to see how $\mathrm{Xi}$, whose style of leadership is expected to be different from his predecessors, will bring China into a better strategic relationship with the United States. Relations between China and the United States has existed for long and covers a variety of fields, ranging from politics, economy, trade, socio-culture to defense and security. It is understood that relations between the two countries have been characterized by many ups-and-downs; many have even called them "uneasy" as well as "love-and-hate" relationships. ${ }^{1}$ Nevertheless, it is argued that the U.S. and China relations is probably the most important bilateral relationship in the world today (Zhao, 2012). Jinghao Zhou (2011: 625-626) claims that

(2009) A Bridge Too Far? Commonalities and Differences between China and the United States. Lanham: Lexington Books; and Lampton, D.M. (2001) Same Bed, Different Dreams: Managing U.S.-China Relations, 1989-200o. Berkeley: University of California Press. These are only few from a huge number of publications about the U.S.-China relations today. 
"U.S.-China relations will profoundly impact on the entire world. The issue of improving the relationship ... has become the most important subject in the twenty-first century." U.S. Secretary of State John Kerry (2014) delivers the same note: "The U.S.-China relationship is the most consequential in the world today ... and it will do much to determine the shape of the $21^{\text {st }}$ century."

This article is to see how the two countries address the challenges to their relationship. Its main point is that the U.S. and China need to manage their differences effectively at the first place in order to build mutual trust and understanding as basics for good relations. The article will highlight differences resulting in misperception and mistrust between the two, followed by the importance of managing these disagreements. Then, several current security challenges to U.S.-China relations are observed, before the article concludes.

\section{Misperception, Ideology differences, and Mistrust}

Basic to the challenges faced by the United States and China is how each responds to misperceptions that often arise within their relations. University of Oklahoma's Peter Gries (2009) writes that the problem of misperception is potentially hindering the relationship between both countries. These misperceptions could take various forms, but the final result tends to be the same: ignorance about what exactly happened has made one country have a negative view of what the other is doing. Gries gives an example: the question of Tibet, which has for long become one of the 'pebbles' in China's diplomacy shoes.

Tibet has been recognized by Beijing as an integral part of Chinese sovereignty so that all measures aimed at Tibetan independence will be considered as a threat to China's national interest. Within this view, it is not uncommon that Beijing responds to such acts repressively. According to Gries, very limited access to find out the real situation in Tibet has made a lot of concerned parties, including the United States, demonstrate their "misrepresenting" which then have an impact on misperceptions about China. This situation is clearly not helping at all, especially when China considers that "misrepresenting" and the resulting misperception has cornered it in the international arena. In response, a group of Chinese nationalists even built anti-CNN.com website, with pages in Chinese and English, "to expose the lies and distortions in the western media [about Tibet]" (Gries, 2009: 222).

The problem of misperception between China and America is thought to be driven by limited knowledge about each other (Gries, 2009: 223). Even though the two nations and governments have been engaged in a great number of cooperation, aimed to strengthen their respective understanding, it is not always easy to develop good views on their relations. In addition, differences in ideology contributes to this misperception. Freedom, liberalism, democracy, and respect for individual rightsbasically the American values-are said to be incompatible with China's closed political system and the authoritarian regime of the Chinese Communist Party (CCP). The two countries have competing ideas about the nature of sovereignty, respect of human rights, economic management as well as power relations that could at times exacerbate their relations (Xinchun Niu, 2012).

Ideological differences and misperception are major challenges to the current U.S.- China relations as pointed by Dingli Shen (2011): "One fundamental reason for the periodic clashes [between the U.S. and China] is diverging values and interests, which means there are times when the two find it difficult to read each other's intentions. Such differences have at times prevented them from developing common values and sharing core interests." Interestingly, it is understood that things have been further compounded by the lack of mutual trust between the two great nations. Shen (2011) adds that "The key reason for the ups and downs in this complex relationship has been a combination of contradictory expectations and a lack of real trust." If this is true, then both Obama and $\mathrm{Xi}$ face a very difficult task to convince their relative nations of the other's good intention, which is the very key to the more positive relations. 
So far there are relatively few indications that these misperception, ideological differences, and lack of mutual trust would be resolved. They may become increasingly difficult to overcome. While misperception, ideological differences, and lack of mutual trust are expected to continue for a long time, the two countries should realize that they too have many common interests to cooperate. If Obama and Xi failed to address this issue well, it is expected that these problems of misperception, ideology difference, and mistrust will continue to color the relations between the two countries to a level that no one can tolerate. Soon, the two states might think that it is imperative to safeguard their national interests by enhancing their military capabilities and prepare for the worst possible scenario: war (Gries, 2009: 231).

An open conflict between the two countries, whose military are among the strongest today, would be a nightmare for the world. Although many argue that war between these great powers is unlikely in the short term, but it is still a possible outcome if their differences are too difficult to manage. As suggested by James Dobbins of the RAND Corporation (2012: 9-14), hot issues from the nuclear-prone Korean Peninsula to relations with Japan and India would potentially drag the two countries into open military confrontation. ${ }^{2}$ In another field, conflicts between the U.S. and China have been much apparent. Economic conflicts, as is shown in the cases of U.S. trade deficit and China being accused of copyright infringement, have resulted in dire consequences for both countries. Although economic conflict may have less destructive impacts than military one, U.S. sees that such a conflict is acceptable because "a strong U.S. economy is not just the basis for a strong defense, it is itself perhaps the best defense against an adventurous China" (Dobbins, 2012: 20).

Presidents Obama and Xi should not only see their differences. Not only do they need to see their respective national security or

\footnotetext{
${ }^{2}$ See also Gompert \& Saunders (2012) for a good note for,
} among others, cyber-war between the U.S. and China. economic interests, they also must seek for solutions to their common problems. This is when bilateral diplomacy as well as multilateral efforts play important role in shaping the greater relations between the two. The U.S. and China should note that "building mutual trust and understanding through cultural exchange program and positive engagement is the best way to reduce the risk of great power war" (Zhou, 2011: 638). The following section will argue more on the importance of managing differences and disagreement in Sino-American relations.

\section{Managing Disagreements}

According to Jinghao Zhou (2011), there are three sources of disagreement between the U.S. and China: political incompatibility, economic competition, and military (security) competition. The two countries have, historically and ideologically, different political systems. China is notorious for its closed, uncertain political system and unstable society-these are to a great extent driving China's response to U.S. hegemonic power. It is within this context that $\mathrm{Xi}$ Jinping has frequently noted for his call of "a new model of great power relations." 3

Examples are abound. One of them is when a Chinese 'dissident' Liu Xiaobo was awarded with the Nobel Prize for peace in 2010. The event soon sparked heated debate in U.S.-China relations. While Beijing "believes that the Nobel Peace Prize Committee's decision is an attempt to deny the legitimate Chinese judicial judgment and undermine the Chinese political system," on the other hand Washington, "view[s] the Chinese political system as directly countering the core values of the West, and they see no fundamental way for the two countries to co-exist" (Zhou, 2011: 630). It is only reasonable to suggest that Obama and Xi should not undermine this issue of incompatible political system as this would only make it more difficult to maintain good relations.

3For good discussion on this topic, see Erickson \& Liff (2014) and Lampton (2013). 
In the economic and trade relations, conflicts also arise when China and the U.S. are now going to different directions. Although the U.S. is still the strongest economy today (and China comes second), but the 2008-2009 economic crises have greatly hampered U.S. economy, while China's economy continues to grow significantly. This growing economy of China could in the long term threaten U.S. hegemony. As U.S. trade deficit with China continues to increase, China maintains its underrated currency and keeps trade barriers (Zhou, 2011: 632). Indeed, "In recent years, Sino-U.S. trade frictions and disputes have increased, with issues concerning fair trade, exchange rates, labor standards, intellectual properties etc. becoming more prominent in Sino-U.S. relations" (Niu, 2012: 68). This is to highlight that economic relations are among the most difficult points in any efforts to establish good relations between the two countries.

American trade deficit, which has occurred since 2006, is among major problems in U.S.-China relations. Some American elites and businesspeople view that this increasing trade deficit is another way to look at deindustrialization in the U.S. and China increasing its capacity in competing with the U.S. for important economic resources. Because of this, Washington has been consistently placing this trade deficit issue within its security interest (Liew, 2010: 659661). The U.S. blame this trade deficit on China's policy to undervalue its currency-the yuan or renmimbi-that would see Chinese products sold inexpensively in the American market.

Not to mention, China has also a great bargaining power over the United States in the form of U.S. foreign debt it holds, which amounted to a total of $\$ 1.268$ trillion in June 2014 (Rapoza, 2014). Both American people and elites "feel anxious with China's growing power and influence" and worry that the U.S. is "at risk of falling behind on a global battle for influence with China" (Zhou, 2011: 627). To many this is understandable, given that China is being more and more assertive towards the U.S. However, Griffith University academic Leong Liew (2010: 656-657) points out that the
U.S. official policy would not label China as a "currency manipulator" as American business and workers in that country are at stake. This proves that China is economically very important for the U.S. Former U.S. Secretary of State Henry Kissinger, who is also a prominent China observer, regards China's economic miracle as one thing that "bring about massive issues of policy that can be postponed only at peril to the world economy ... [It constitutes] a shift in the center of gravity of world affairs from the Atlantic to the Pacific" (Kissinger, 2004). It is interesting to see how Obama and $\mathrm{Xi}$, along with their respective top economic advisers, would address to these economic and trade issues as a basic, common ground for their relations.

As suggested by Jinghao Zhou (2011: 633), the U.S. views China's military development as one that will "challenge the U.S. military power in Asia and may challenge the capability of the U.S. military operations worldwide." American view on China's military development is somewhat understandable given the annual rise of military budget and the widely spread belief (especially among U.S. allies in Asia Pacific) of China's intention to become a regional hegemonic power. Interestingly, China also sees the U.S. in similar way. The rising presence of U.S. military, as a part of what is known as U.S. "pivoting in Asia", is a major worrying situation China would face. Therefore, it is of China's national interest that it modernizes its military, given much support from the economic growth it enjoys.

The difficult security situation is expected to continue during the Obama and $\mathrm{Xi}$ respective leadership as it would define the greater picture of their relations. They need to cooperate in order to prevent such security disagreement from escalating into conflicts. Cooperation in the security issues is vital because "neither the U.S. nor China is able to dominate each other. A military clash between them would exhaust both countries" (Zhou, 2011: 634). Governments and people of both countries need to notice this as the outcome of security issues is very important to their cooperation in many other fields. 


\section{Several Current Security Issues}

There have been many current security issues which have potentials to either develop or disturb the U.S.-China relations. Among them are terrorism, the South China Sea conflict, the Syrian crisis, the Edward Snowden case, and the Chinese Air Defense Identification Zone (ADIZ), just to name a few.

The issue of terrorism has become one of the central themes in U.S.-China relations since 9/11. As widely known, terrorist attacks in the United States on September11, 2001 were immediately followed by an allencompassing policy, and in many cases unilateralist, "war on terrorism" which is run by the United States in some places in the world. President George W. Bush presumptuously asserted that countries were divided into those which were willing to jointly combat terrorism and those which were not. Countries that did not want to fight terrorists were labeled as "terrorist states" and therefore had the potential to be the subject of a U.S. attack. China, which has not had a harmonious relationship with Uyghur "extremist" groups in Xinjiang, initially welcomed American call to combat terrorism. By doing so, Beijing seemed to get a meaningful boost to intensify repressive measures it considers as necessary to secure the situation in Xinjiang, to prevent "radical Islam" groups from building relationships with similar groups in several Central Asian countries or seeking Uyghur independence. Anti-terrorism campaigns also allow China to improve its image as a good international citizen and contribute to security and stability of the region, for example by helping to supply food to Afghan refugees and donating $\$ 150$ million reconstruction fund to Afghanistan (Glaser, 2002: 223-224).

Director at the Center for American Studies, Fudan University, Xinbo Wu regards the September 11 attacks as bringing a significant change in U.S.-China relations. Prior to the attacks, the United States viewed the rising China as a security threat, but it changed considerably when terrorism was viewed as U.S. main threat and China was then a "potential partner in the war on terrorism" (Wu, 2004: 120-121). Yet, this situation only prevailed for a short time as Washington preemptive strikes in fighting terrorism concerned Beijing. Bonnie Glaser, a Chinese expert with the Center for Strategic and International Studies, noted that the later development of the "global war on terrorism" has brought relations between the two countries return to the "normal" situation. The 11 September 2011 attacks had "changed the world for the United States, but for China, it is the U.S. response that has changed the world" (Glaser, 2002: 223). In support of the fight against terrorist attacks, the United States increased its military presence by building 13 military bases in Central Asia, including one in Uzbekistan and another in Kyrgyzstan. These military bases have been called to be withdrawn by the Shanghai Cooperation Organization (SCO), a forum in the region of which China is a member. Increased U.S. presence in the region is seen by China as a long-term strategy to encircle and suppress China, especially with the U.S. efforts to increase its influence in India and Pakistan. Another concern of the Chinese was when the United States managed to "control" Afghanistan, it would use military force stationed there and those Central Asian bases to attack targets or other countries, including China.

According to Glaser (2002: 226-227), there is one thing that has not changed from the United States and China relations since the events of September 11: the mutual suspicion in a variety of issues. This includes, among others, China's military buildup, increased U.S. presence in the region, and the Taiwan issue. The latest issue has been one of the major obstacles in building the sound relations between the U.S. and China. Indeed, China has made Taiwan among its core interest and stated that "the Taiwan question is the most important and sensitive central question in China-U.S. relations, and that the proper handling of this question ... hold[s] the key to sound and stable growth of China-U.S. 
relations" (Wu, 2011: 2).4 The U.S., on the other hand, has good non-diplomatic relations with Taiwan. Furthermore, based on the provisions of the Taiwan Relations Act, the U.S. is prepared to intervene militarily if China attacks Taiwan. The act has severely hurt the Sino-U.S. relations, making solutions to the Taiwan issue are not easy to find.

It is also argued that mutual suspicion is also behind the current security challenges faced by both Obama and Xi in the South China Sea issue. China and other five countriesTaiwan, Vietnam, the Philippines, Malaysia and Brunei Darussalam-are claiming the ownership of oil-rich areas within the disputed sea. Things have been deteriorating in recent years as China stands firm on its claim and rejects any multilateral attempts to solve the problem. In the recently published new Chinese passport, Beijing prints the map of China with the disputed sea as part of its territory; this would be responded angrily by its claimant neighbors. That "China claims that the South China Sea was a core interest of the nation and oppose any attempt to internationalize the South China Sea issues" (Zhou, 2011: 627) has prompted Vietnam and the Philippines to work with the U.S. to balance Chinese power. It seems that these countries have shared the U.S. view that the way China deals with the issue reflects "China's imperialism is on full display" (Lyons, in Zhou, 2011: 633).

Both presidents also face quite similar challenge when they are dealing with the Syrian crisis. The Bashar al-Assad authoritarian regime in Syria has been condemned internationally for its violent response to the pro-democracy movement who calls for his resignation as president. While President Obama had intention to send U.S. troops to attack Damascus and help the Syrian opposition fighting against the Assad regime, China seemed reluctant to recognize that such

4See also Cheng-yi Lin \& Royeds. (2011) to find out the latest development on the issue.

${ }_{5}$ Following the ongoing wide-scale protest in Hong Kong, which began on September 2014, China and the U.S. once again find themselves at odds. China even accuses that the approach was necessary. It is argued that among the reasons why the crisis in Syria has not been solved peacefully is China's (and Russia's) support to the regime, based partly on non-intervention which has been among China's major foreign relations principles for long (Minter, 2013).

The U.S. and China elites had been also at odds when it was found out that Hong Kong, a Chinese territory, was the place of Edward Snowden, former U.S. intelligence analyst turned fugitive, to depart for Russia. Snowden leaked a number of top-secret information he gathered while working with the U.S. National Security Agency (NSA), including the shocking subject that the NSA tapped the mobile phones of several international leaders, which even includes that of Germany's Angela Merkel, a U.S. ally. China stated that nothing wrong with Hong Kong action, but the U.S. said that it "undermined 'trust' in bilateral ties" (BBC News, 2013). 5 The similar situation could be repeated in the events following the 23 November 2013 announcement of China's Air Defense Identification Zone (ADIZ). The Chinese authorities required all aircrafts entering the zone to register with them and maintain radio communication. The problem is that China's ADIZ is overlapping with those of Japan, South Korea, and Taiwan. It is also thought to be based on China's claim over disputed water in the East China Sea. While many observers call the China's ADIZ as destabilizing and unacceptable, it is interesting to see how the U.S. - as a powerful ally of Japan, South Korea, and Taiwan-would respond to this. Policy based on failed observation and wrong assumption will to a great extent endanger Washington's relations with Beijing. This and other security challenges need to be addressed effectively if both countries are to avoid the "Thucydidean Trap", a clash between rising and established powers

U.S. may be behind the so-called "Umbrella revolution" in which many elements of Hong Kong society demanded that the Chinese government grant them full democracy under the concept of 'one country, two systems.' See Zachary Keck (2014). 
which have precedence in our history (see Tiezzi, 2014).

At home, needless to say, both presidents are facing no less domestic problems than their efforts to address all these challenges in the bilateral relations. President Obama, who is currently not supported by the majority of Republicans in Congress, must strive to convince the decision makers in the U.S. foreign policy, whose perceptions are divided at most times, that they need to build trust in relations with China. Xi's task is no less complicated. Factions within the body of the CCP is not just competing for access to economic and development strategy, but they also disagree on how China should view the power of the United States. The fact that China holds the majority of U.S. foreign debt make many Chinese leaders believe that China should not be underestimated by the United States in a variety of issues that they differed.

This is not to say that the U.S. and China are expecting a depressing future of their relations. Despite all the problems, relations between the two countries are also developing positively due to increase in cooperation in non-traditional issues such as health, environment, energy, and culture. A good, stable strategic partnership between the two countries is very important for the world. As David Lampton puts it, "There is no global issue that can be effectively tackled without Sino-American cooperation" (see Zhou, 2008: 177). In so doing, both need to realize that "If respect for each other's core interests is one leg of the partnership, development of common interests is the other" (Wu, 2011: 9).

\section{Conclusion}

The United States and China are both now targeting Asia Pacific as an important region to assert and maintain their influence. Washington must have realized that a stronger presence in the Asia Pacific region will not be easy. Whilst it is true that it has had very close strategic relationships with a number of countries in the region (e.g. Japan, South Korea, Taiwan, and Singapore), but the potential for disputes with China still cannot be ruled out. As for Beijing, it cannot be said to swing with ease, because its potential economic power and military capability has made many people in the region worried about China's "peaceful rise." By examining several political, economic, and security issues, this study argues that the challenges faced by the two countries will focus on their efforts to maintain influence in the Asia-Pacific, which is triggered by American fears on the so-called "China threat" and a strong belief in China that U.S. hegemony is widely unacceptable.

It can be concluded that most disagreements between the U.S. and China are the result of different views on global politics and the lack of trust and willingness to understand each other. The U.S. and China should not regard these problems as trivial issues because they have been potential to disrupt relations between the two. This has prompted many to follow a view that "the two sides share goals but differ on tactics, or they share interests but the interests are prioritized differently, leading to a more tumultuous U.S.China relationship" (American Foreign Policy Interests, 2010: 192). Today's Sino-American relations have perfectly reflected Deng Xiaoping's view quoted in the beginning of this article that the relations contain no simple things.

At the end of the day, the development of relations between the U.S. and China would have always characterized the nature of international relations of our times. Both countries are aware that they have many differences, but this shall not lead to disagreement and mistrust. The Cold War era had been long gone, but current and future American and Chinese leaders should be able to reduce misperception, adjust the differences of ideology, and build mutual trust-making these the driving force for a good relationship. This has been the main challenge for U.S.China relations for many years to come.

$$
* * *
$$

\section{Bibliography}

\section{Books}

Guo, S \& Guo, B. (2010)3o Years of China-U.S. Relations: Analytical Approaches and Contemporary Issues. Lanham: Lexington Books. 
Grafstein, R. \& Wen Fan eds. (2009) A Bridge Too Far? Commonalities and Differences between China and the United States. Lanham: Lexington Books.

Hao, Y. (2010) Sino-American Relations: challenges ahead. Surrey: Ashgate.

Lampton, D.M. (2001) Same Bed, Different Dreams: Managing U.S.-China Relations, 1989-200o. Berkeley: University of California Press.

Lin, C \& Roy, D. eds. (2011) The Future of United States, China, and Taiwan Relations. New York: Palgrave Macmillan.

Jones, H. (2010) Chin America: The Uneasy Partnership that Will Change the World. New York: McGraw Hill.

\section{Journals and Other Printed Articles}

'U.S.-China Relations' (2010) American Foreign Policy Interests: The Journal of the National Committee on American Foreign Policy, 32 (3), pp. 191-193.

Dobbins, J. (2012) War with China. Survival: Global Politics and Strategy, 54 (4), pp. 7-24.

Garrett, B. (2006) US-China Relations in the Era of Globalization and Terror: a framework for analysis. Journal of Contemporary China, 5 (48), pp. 389415 .

Glaser, B.S. (2002) Sino-American Relations beyond September 11. American Foreign Policy Interests: The Journal of the National Committee on American Foreign Policy, 24 (3), pp. 223-229.

Gries, P.H. (2009) Problems of Misperception in U.S.-China Relations. Orbis, Spring, pp. 220-232.

Kissinger, H. (2004) America's Assignment. Newsweek, 8 November.

Lampton, D.M. (2013) A New Type of MajorPower Relationship: Seeking a Durable Foundation for U.S.-China Ties. Asia Policy, 16, July, pp. 51-68.

Liew, L.H. (2010) US Trade Deficits and SinoUS Relations. Journal of Contemporary Asia, 40 (4), November, pp. 656-673.

Lyons, J. (2011) China's Imperialism on Full Display. Washington Times, 11 January.
Mearsheimer, J.J. (2010) The Gathering Storm: China's Challenge to US Power in Asia. The Chinese Journal of International Politics, 3 (3), pp. 381396.

Niu, X. (2012) Sino-US Relations: Ideological Clashes and Competitions. China International Studies, May/June, pp. 61-78.

Peng, Y. (2007) Sino-American relations: new changes and new challenges. Australian Journal of International Affairs, 61 (1), pp. 98-113.

$\mathrm{Wu}, \mathrm{X}$. (2004) The Promise and Limitations of a Sino-U.S. Partnership. The Washington Quarterly, 27 (4), Autumn, pp.115-126.

Yan, X. (2010) The Instability of China-US Relations. The Chinese Journal of International Politics, 3 (3), pp. 263292.

Yuliantoro, N.R. (2012) Pemilihan Presiden Tahun 2012 dan Tantangan bagi Politik Luar Negeri Amerika Serikat, research paper, FISIPOL Universitas Gadjah Mada, Yogyakarta.

Zhang, J \& Zheng, X. (2012). The Role of Nontraditional Security in China-US Relations: common ground or contradictory arena? Journal of Contemporary China, 21 (76), pp. 623636.

Zhou, J. (2008) Does China Rise Threaten the United States? Asian Perspective, 32 (3), pp. 171-182.

. (2011) American Perspective versus Chinese Expectation on China's Rise. International Journal of China Studies, 2 (3), December, pp.625-645.

\section{Online Articles}

Clinton, H. (2011) America's Pacific Century. Foreign Policy [Online], 11 October. Available from: <http://www.foreignpolicy.com/articl es/2011/10/11/americas_pacific_cent ury > [Accessed on 18 October 2014].

Cronin, P.M. (2012) 10 big questions for Obama, Romney on Asia. CNN.com [Online], 18 April. Available from: <http://edition.cnn.com/2012/04/18 
/opinion/cronin-asia-ten-

questions/index.html > [Accessed on 15October 2014].

Erickson, A.S. \& Liff, A.P. (2014) Not-So-Empty Talk: The Danger of China's "New Type of Great-Power Relations" Slogan. Foreign Affairs [Online], 9 October. Available from: $<$ http://www.foreignaffairs.com/artic les/142178/andrew-s-erickson-andadam-p-liff/not-so-empty-talk> [Accessed on 11 November 2014].

Edward Snowden case: US rebukes China (2013) BBC News [Online], 12 July. Available from: <http://www.bbc.com/news/worldus-canada-23281575> [Accessed on 18 October 2014].

Gompert, D. \& Saunders, P. (2012) The Future of Sino-American Relations. The National Interest [Online], 12 January. Available from: $<$ http://nationalinterest.org/commen tary/the-future-sino-americanrelations-6358> [Accessed on 19 October 2014].

Keck, Z. (2014) China Claims US Behind Hong Kong Protest. The Diplomat [Online], 12 October. Available from: $<$ http://thediplomat.com/2014/10/ch ina-claims-us-behind-hong-kongprotests/> [Accessed on 19 October 2014].

Kerry, J. (2014) Remarks on U.S.-China Relations. U.S. Department of State [Online], 4 November. Available from <http://www.state.gov/secretary/rem arks/2014/11/233705.htm $>$ [Accessed on 11 November 2014].

Minter, A. (2013) Syria Attack Has China Outraged - at U.S. Bloomberg [Online], 4 September. Available from: <http://www.bloomberg.com/news/p rint/2013-09-04/syria-attack-haschina-outraged-at-u-s-.html> [Accessed on 19 October 2014].

Rapoza, K. (2014) China Cuts U.S. Debt Holding Again. Forbes [Online], 18 August. Available from: <http://www.forbes.com/sites/kenra poza/2014/o8/18/china-cuts-u-s- debt-holdings-again/> [Accessed on 19 October 2014].

Remarks By President Obama to the Australian Parliament (2011) The White House [Online], 17 November. Available from:

$<$ http://www.whitehouse.gov/thepress-office/2011/11/17/remarkspresident-obama-australianparliament $>$ [Accessed on 18 October 2014].

Shen, D. (2011) How to Improve China-US Trust. The Diplomat [Online], 4 March. Available from: <http://thediplomat.com/2013/11/ho w-to-improve-china-us-trust/> [Accessed on 19 October 2014].

Tiezzi, S. (2014) Has the Thucydidean Trap Already Sprung on China and the US? The Diplomat [Online], 10 July. Available from: $<$ http://thediplomat.com/2014/07/h as-the-thucydidean-trap-alreadysprung-on-china-and-the-us/> [Accessed on 11 November 2014].

Wu, X. (2011) China and the United States Core Interests, Common Interests, and Partnership, the United States Institute of Peace Special Report No. 277, 2011. Available from: <http://www.usip.org/sites/default/fi les/SR277.pdf> [Accessed on 15 October 2014].

Zhao, S. (2012) SinoUS relations the most important: Panett a. China Daily, 18 September. Available from:

$<$ http://www.chinadaily.com.cn/china/ 2012-09/18/content_15765924.htm> [Accessed on 19 October 2014]. 